\title{
Life cycle inventory processes of the ArcelorMittal Poland (AMP) S.A. in Kraków, Poland-basic oxygen furnace steel production
}

\author{
A case study
}

\author{
Boguslaw Bieda
}

Received: 8 September 2011 / Accepted: 12 December 2011 /Published online: 11 January 2012

(C) The Author(s) 2012. This article is published with open access at Springerlink.com

\begin{abstract}
Purpose The goal of this paper is to describe the life cycle inventory (LCI) approach to steel produced by ArcelorMittal's Basic Oxygen Furnace (AMBOF) in Kraków, Poland. The present LCI is representative for the reference year 2005 by application of PN-EN ISO 14040:2009 (PN-EN ISO 2009). The system boundaries were labeled as gate-togate (covering a full chain process of steel production). The background input and output data from the basic oxygen furnace (BOF) steelmaking process has been inventoried as follows: pig iron, scrap, slag forming materials $(\mathrm{CaO})$, ferroalloys, $\mathrm{Al}$, carbon and graphite carburizer (material for carburization of steel), isolating powder, consumption of energy and fuels including natural gas, blast furnace gas and coke oven gas, electric energy, steam, air, oxygen, industrial water and heat, emission of air pollutants, waste, internal transport and land use.

Main feature LCI steelmaking process was developed mainly on the basis of the following sources: site-specific measured or calculated data, study carried out by the AGH University of Science and Technology in Kraków, AMP Environmental Impact Report, study carried out by the Faculty of Mining Surveying and Environmental Engineering of the AGH University of Science and Technology in Kraków, literature information and expert consultations. The functional unit (FU) is represented by $1,677,987 \mathrm{Mg}$ of steel, produced by BOF steelmaking process. Time coverage is 2005 . Operating
\end{abstract}

Responsible editor: Zbigniew Stanislaw Klos

B. Bieda $(\bowtie)$

AGH University of Science and Technology,

Management Department,

ul. Gramatyka 10,

30-067 Kraków, Poland

e-mail: bbieda@zarz.agh.edu.pl parameters as well as air emissions associated with the BOF steelmaking process were presented. The production data (steel) was given. The emissions of $\mathrm{SO}_{2}, \mathrm{NO}_{2}, \mathrm{CO}, \mathrm{CH}_{4}$, $\mathrm{CO}_{2}$, dust, heavy metals $(\mathrm{Cr}, \mathrm{Cd}, \mathrm{Cu}, \mathrm{Pb}, \mathrm{Ni}$ and $\mathrm{Mn})$ and waste (slag and gas cleaning sludge) are the most important outcomes of the steel process.

Results With regard to $1,677,987 \mathrm{Mg}$ of steel produced by AMBOF, the consumption of natural gas, blast furnace gas and coke oven gas amounted to 10,671,997, 755,094 and $13,222,537.6 \mathrm{~m}^{3} /$ year, respectively. Electric energy, steam, air, oxygen and heat input amounts were in the order of 45,003,611.3 kWh, 21,646.03 Mg, 107,592,526 m³, $90,611,298 \mathrm{~m}^{3}$ and 16,779.87 GJ, respectively. Direct emissions in air of $\mathrm{SO}_{2}, \mathrm{NO}_{2}$, dust, $\mathrm{Cr}, \mathrm{Cd}, \mathrm{Cu}, \mathrm{Pb}, \mathrm{Ni}, \mathrm{Mn}, \mathrm{CO}$ and $\mathrm{CH}_{4}$ from three converters (Nos. 1-3) were on the order of 28.966, 71.331, 752.05, 0.025, 0.024, 0.0216, 0.0156, 0.0163, $1.5694,540.449$ and $0.364 \mathrm{Mg}$, respectively. Total $\mathrm{CO}_{2}$ emission was $138,374 \mathrm{Mg}$. The amounts of slag and gas cleaning sludge were $276,709.64$ and $16,749 \mathrm{Mg}$, respectively.

Conclusions The LCI study resulted in the development of a database with a vast inventory of data regarding steelmaking process in AMBOF referring to the year 2005. The output of the AMBOF LCI study is a set of gate-to-gate LCI data for steel production in BOF technology. This is the first tentative study to express steel production in Poland in terms of LCA/LCI in the steelmaking industry. The FU chosen for the present study is $1,677,987 \mathrm{Mg}$ of steel produced in a classical BOF. The quality of data input in this LCI study is very good. The rules were used in accordance with ISO Standard for LCA. The methodological approach and boundaries that were made are transparent and fully documented. The purpose of this study is to help AMP authorities solve environmental and technical aspects as well as to train steel industry people in the field of life cycle 
assessment. In addition, this study can be extended to other processes involved in steelmaking route (via sintering plant/ hot rolling plant). Moreover, these results move the LCI study on the steelmaking process one step forward.

Recommendations and outlook The LCI offers environmental information consisting of the list of environmental loads. The impact assessment phase aims to present more understandable results from the inventory analysis, and life cycle impact assessment (LCIA) will be the direction for future research. Another issue to discuss is the integration of LCA with risk assessment for industrial processes.

Keywords Air emissions - Basic oxygen furnace (BOF) . Blast furnace gas · Coke oven gas · Converter gas · Life cycle inventory $(\mathrm{LCI}) \cdot$ Natural gas $\cdot$ Poland $\cdot$ Steelmaking process

\section{Introduction}

This paper describes an LCI study of steel produced by the AMBOF in Kraków, Poland. The framework of the study was originally carried out for 2005 data. Average input and output data for 2005, which has been shown in Table 3, are used for the purpose of this study.

Since no LCA has ever been conducted on the steelmaking production in Poland, this study is the first work about LCI of steelmaking process. The LCI study was conducted following the requirements of the International Standards ISO 14040: 2009. The paper is organized as follows: Introduction is presented first. Then, the goal and scope of the study are stated followed by main features including the LCI of the AMBOF installation. Subsequently, the presentation of data analysis on emission results and conclusions are given.

\subsection{Introduction to AMP}

In general, liquid pig iron fed from the blast furnace is moved into two mixers which are connected via multicyclones to a fabric filter, which is used for disposal of graphite powder. The reduction of sulfur from pig iron is very important in the manufacture of steel. Consequently, magnesium and calcium are introduced through the lance in the desulfuration unit used for this operation. This process required two ladles with the average capacity of $125 \mathrm{t}$ each.
The minimal sulfur contents of pig iron after this operation is generally less than $0.005 \%$.

The steel in AMBOF is manufactured in oxygen steelmaking converters, with a total capacity of $160 \mathrm{t}$ of materials, mainly through refining of pig iron and ferrous (steel) scrap with a $99.5 \%$ oxygen content blast. The converter furnace comprises a refractory lined steel body inclined at an angle to the horizontal. Average oxygen consumption was not to rise above $50 \mathrm{~m}^{3} / \mathrm{t}$ steel assuming that the average blast intensity supply is $320 \mathrm{~m}^{3} / \mathrm{min}$ of oxygen value and the time of blast and the time of melt processes are $22 \mathrm{~min}$ and $43 \mathrm{~min}$, respectively. Oxygen is introduced from the top of the furnace into the bath through vertical lance at pressure not exceeding 1.6 MPa. In addition, gas ( $\mathrm{Ar}$ or $\mathrm{N}$ ) is introduced through the converter bottom with velocity ranging from 0.01 to $0.06 \mathrm{~m}^{3} / \mathrm{Mg} / \mathrm{min}$. The gas temperature on the converter outside is generally about $1,400 \div 1,700^{\circ} \mathrm{C}$. Before the melt process, the slag forming substances $(\mathrm{CaO})$ are dropped into the converters. During the melt process, converter gas and slag are produced, which are transferred to the storage yard and recycled. Operating parameters of the AMBOF are given in Table 1. At regular intervals, molten steel is tapped from the converters into the steel tundish where ferroalloys are dropped. Tundish is transported to the steel treatment station (chemical composition makeup operation). The steel is then cleaned of oxygen (by addition of $\mathrm{Al}$ ) and gases (blow off using Ar). Finally, the steel is delivered to the Continuous Steel Casting Department.

By the end of 2005, the total steel production output (three BOFs) reached 1,677,987 Mg (Mittal 2007). AMBOF has three (KT-1, KT-2 and KT-3) converters. The actual volume of the steel produced by each of the converters is 1,000,000 Mg (Mittal 2007). In 1996, converters were equipped with a combined blow facility of MannesmannDemag TBM technology as well as the Krupp Polysius pig iron desulfurization technology. Table 1 reports the operating parameters of the AMBOF's converters.

Above the converters, the OKG-100-3g type boilers are installed. Using the heat from the converter gas streams at elevated temperature, the boilers produce saturated steam with a pressure value of $2.3 \mathrm{MPa}$ at the maximal output (capacity) of $240 \mathrm{Mg} / \mathrm{h}$ in the top period of carbon burning. During the technological stoppage, natural gas is burned in boilers with the output value of about $40 \mathrm{Mg} / \mathrm{h}$.
Table 1 AMBOF operating parameters

\begin{tabular}{lllll}
\hline $\begin{array}{l}\text { BOF } \\
\text { number }\end{array}$ & $\begin{array}{l}\text { Start } \\
\text { [year] }\end{array}$ & $\begin{array}{l}\text { Modernization } \\
\text { (rebuilding) [year] }\end{array}$ & $\begin{array}{l}\text { Nominal productivity } \\
{[\mathrm{Mg} / \text { year] }}\end{array}$ & $\begin{array}{l}\text { Total capacity } \\
{[\mathrm{Mg}]}\end{array}$ \\
\hline 1 & 1966 & 1998 & $1,000,000$ & 160 \\
2 & 1966 & 1988 & $1,000,000$ & 160 \\
3 & 1971 & 1978 & $1,000,000$ & 160 \\
\hline
\end{tabular}


Industrial water input reaches $12,246,295 \mathrm{~m}^{3}$ for converter gas cleaning process. The Vistula and Dłubnia rivers serve as industrial water supply sources for the AMP (see Fig. 2). Water softening and water demineralization for BOF are produced in the ArcelorMittal Power Plant (AMPP) (Bieda 2011).

The first stage of water demineralization is conducted by water softening (decarbonization), coagulation and clarification. This problem was solved thanks to ion exchange. The function of ion exchange is the removal of dissolved polluted solids in ionic form. The anion exchangers remove strong acid anions, $\mathrm{SiO}_{2}$ as well as $\mathrm{CO}_{2}$. The regeneration of the anion exchangers is typically carried out with sodium hydroxide. After the regeneration of anion exchangers, waste water is mixed with the decarbonized slurry and deposited at the other sludge disposal unit. The second chemical water pretreatment scenario is achieved as a result of a three-stage process: (i) decarbonization with a calcium hydroxide (lime hydrate), (ii) filtration and (iii) ionite softening. The water that comes into contact with lime water (4\% saturated calcium hydroxide solution) in the Virbos reactor yields the granulated product deposed in reactor and colloidal particles conducted to the clarifiers. The coagulant, ferrous sulfate (copperas), is added to neutralize the charges on the particles which then agglomerate to form a floc and to facilitate the removal of colloidal particles, for example, gravity setting. Filtration, the second step, is the removal of particulate solids from water after coagulation, and it is done by pressure filters, generally applicable to high resistance filter cakes. In the ionite softening step, cations such as calcium and magnesium are replaced with natrium cation. Finally, water (soft water) after the ionite softening process goes to customers and dehydrated sludge is deposited at the other sludge disposal unit. The average chemical composition of the hydrated waste from the converter gas cleaning process has been presented in the Table 2 (Mittal 2003).

AMP consists of four plants located in Dąbrowa, Kraków, Sosnowiec and Swiętochłowice. It boasts a full production system ranging from pig iron to final, highly processed steel products. Today, AMP is the world's leading steel company, with an industrial presence in over 20 countries spanning over four continents and with operations in more than 60 countries. In 2010, AMP generated a revenue of $\$ 78.0$ billion and crude steel production of 90.6 million tonnes, representing approximately $8 \%$ of world's steel output (Mittal 2003).

\section{Goal, scope, terminology and definitions}

The goals of this study were to:

- Develop generic Polish LCA method limited to LCI data for AMBOF input/output datasets in the steel production case study with the view to facilitating the range of emerging impact assessment methods in future studies covering the year 2005;

- Produce national and regional LCI data suitable for the steel industry as well as other industries; and

- Promote the development of LCI and/or LCA research in Poland.

The data used in the study is obtained from the following sources:

- Site-specific measured or calculated data (Mittal 2003);

- Data from peer-reviewed literature;

- LCA study carried out on behalf of the Management Department of the AGH University of Science and Technology, the Polish Academy of Sciences in Kraków (Kulczycka and Henclik 2009);

- Study carried out by the Faculty of Mining Surveying and Environmental Engineering of the AGH University of Science and Technology in Kraków (Mazur et al. 2006);

- AMSPP Environmental Impact Report (Mittal 2007);

- Company's internal information (data obtained from personal communication with AMP Environmental Department director); and

- Expert consultation.

The data represents an integral AMP situation with global coverage of the steelmaking process. The FU for the present study is $1,677,987 \mathrm{Mg}$ of steel produced in a steelmaking (BOF) plant. The system boundaries, which define the scope of the study, are shown in Fig. 1. Gate-to-gate data, i.e., input and output at the process level, covers all operations required for steel production in AMBOF from upstream raw materials (i.e., the gate) to end steel product ready to be shipped from the BOF plant (i.e., gate). Raw fuel mining and means of external transportation of natural gas,

Table 2 Mean chemical composition of the hydrated waste from the converter gas purification process

\begin{tabular}{lllllllllllllllll}
\hline Sludge source & \multicolumn{1}{ll}{ Sludge components (mass wt.\%) } \\
\cline { 2 - 13 } & $\mathrm{Fe}$ & $\mathrm{FeO}$ & $\mathrm{Cr}$ & $\mathrm{SiO}_{2}$ & $\mathrm{CaO}$ & $\mathrm{MgO}$ & $\mathrm{Al}_{2} \mathrm{O}_{3}$ & $\mathrm{Mn}$ & $\mathrm{Zn}$ & $\mathrm{Pb}$ & $\mathrm{Ni}$ & $\mathrm{Cd}$ & $\mathrm{C}$ & $\mathrm{S}$ \\
\hline Converter gas cleaning process & 63.62 & 1.52 & 0.04 & 1.30 & 2.35 & 0.24 & 0.25 & 0.34 & 1.60 & 0.31 & 0.01 & 0.005 & 0.40 & 0.04 \\
\hline
\end{tabular}




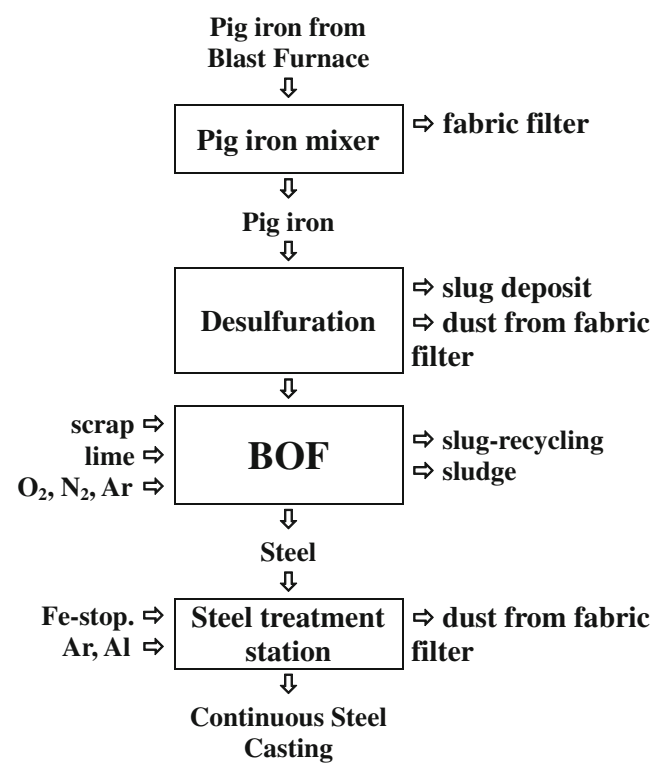

Fig. 1 System boundary of BOF process - different processes investigated for the steel production chain of BOF plant installed in AMP

manufacture of downstream products, their use and end of life were not included. The internal transport (pig iron ladles railways of $1,100 \mathrm{~m}$ ) was included, and land use of around $380,000 \mathrm{~m}^{2}$ was taken into account. The electricity consumption required in the steelmaking process is covered by internal properly produced electric energy, which uses steelwork gases (blast furnace gas and coke oven gas), natural gas and coal powder. The importation of electricity is necessary only in cases of an operational stop. Production data of main energy carriers is given in Table 3. The power plant operates 365 days a year and $24 \mathrm{~h}$ each day.

\subsection{LCI of AMSP}

The consumption of blast furnace gas and coke oven gas of AMBOF in 2005, according to the AMP Environmental Impact Report (Mittal 2007), has been presented in Table 3. Coke oven gas is the main fuel used for the steelmaking process in AMBOF, followed by natural gas. The converter gas cleaning process is achieved in three steps: wet scrubbing, cleaning units and using industrial water passed in closed cycle through: (i) a clarification unit (DORR tank), (ii) a water cooling bed and (iii) a pump unit. The converter gas cleaning system involved in the steelmaking process has been presented in Fig. 2 (Szuba 2004).

\section{LCI methodology}

The LCI analysis involved the collection and calculation of data and procedures to quantify the relevant input and output of the product system (Iosif et al. 2009). Also, LCI
Table 3 Life cycle inventory for AMBOF generation process (2005). Flows are representative of the production of $1,677,987 \mathrm{Mg}$ of steel

\begin{tabular}{|c|c|c|}
\hline Flux & Quantity & Units \\
\hline \multicolumn{3}{|l|}{ Input } \\
\hline \multicolumn{3}{|l|}{ Fuels and energy } \\
\hline Natural gas & $10,671,997$ & $\mathrm{~m}^{3}$ \\
\hline Blast furnace gas & 755,094 & $\mathrm{~m}^{3}$ \\
\hline Coke oven gas & $13,222,537$ & $\mathrm{~m}^{3}$ \\
\hline Electric energy & $45,003,611$ & $\mathrm{kWh}$ \\
\hline Steam & $21,646.0323$ & $\mathrm{Mg}$ \\
\hline Air & $107,592,526$ & $\mathrm{~m}^{3}$ \\
\hline Oxygen & $90,611,298$ & $\mathrm{~m}^{3}$ \\
\hline Heat & $16,779.87$ & GJ \\
\hline \multicolumn{3}{|l|}{ Materials } \\
\hline Pig iron (liquid) & $1,490,74$ & $\mathrm{Mg}$ \\
\hline Pig iron (solid) & 470 & $\mathrm{Mg}$ \\
\hline Scrap (steel) & 394,344 & $\mathrm{Mg}$ \\
\hline Scrap (pig iron) & 4,866 & \\
\hline Slag forming materials (coagulator) & 537 & $\mathrm{Mg}$ \\
\hline $\begin{array}{l}\text { Ferroalloys }(\mathrm{Fe}-\mathrm{Mn}, \mathrm{Fe}-\mathrm{Mn}-\mathrm{Si} \text {, } \\
\text { Fe-Si-Al, } \mathrm{Fe}-\mathrm{Si}-\mathrm{C}, \mathrm{Fe}-\mathrm{P})\end{array}$ & $12,014.8$ & $\mathrm{Mg}$ \\
\hline $\mathrm{Al}$ & $4,244.8$ & $\mathrm{Mg}$ \\
\hline Niob & 16.8 & $\mathrm{Mg}$ \\
\hline Carburizer $^{\mathrm{a}}$ & 1,007 & $\mathrm{Mg}$ \\
\hline Lime & 100,696 & $\mathrm{Mg}$ \\
\hline Dolomite & 923 & $\mathrm{Mg}$ \\
\hline Industrial water & $12,246,295$ & $\mathrm{~m}^{3}$ \\
\hline \multicolumn{3}{|l|}{ Output } \\
\hline \multicolumn{3}{|l|}{ Product } \\
\hline Steel & $1,667,987$ & $\mathrm{Mg}$ \\
\hline \multicolumn{3}{|l|}{ Emissions to air } \\
\hline $\mathrm{SO}_{2}$ & 28.966 & $\mathrm{Mg}$ \\
\hline $\mathrm{NO}_{2}$ & 71.331 & $\mathrm{Mg}$ \\
\hline Dust & 752.05 & $\mathrm{Mg}$ \\
\hline $\mathrm{Cr}$ & 0.025 & $\mathrm{Mg}$ \\
\hline $\mathrm{Cd}$ & 0.024 & $\mathrm{Mg}$ \\
\hline $\mathrm{Cu}$ & 0.0216 & $\mathrm{Mg}$ \\
\hline $\mathrm{Pb}$ & 0.0156 & $\mathrm{Mg}$ \\
\hline $\mathrm{Ni}$ & 0.0163 & $\mathrm{Mg}$ \\
\hline $\mathrm{Mn}$ & 1.5694 & $\mathrm{Mg}$ \\
\hline $\mathrm{CO}$ & 540.449 & $\mathrm{Mg}$ \\
\hline $\mathrm{CO}_{2}$ & 138,377 & $\mathrm{Mg}$ \\
\hline $\mathrm{CH}_{4}$ & 0.364 & $\mathrm{Mg}$ \\
\hline \multicolumn{3}{|l|}{ Waste } \\
\hline Slag & $276,709.64$ & $\mathrm{Mg}$ \\
\hline Gas cleaning sludge & 16,749 & $\mathrm{Mg}$ \\
\hline $\mathrm{Fe}$, steel & $24,532.038$ & $\mathrm{Mg}$ \\
\hline Melting loss & $12,035.74$ & $\mathrm{Mg}$ \\
\hline Consumed refractory materials & 68 & $\mathrm{Mg}$ \\
\hline $\mathrm{Al}$ & 2.69 & $\mathrm{Mg}$ \\
\hline $\mathrm{Cu}$, brass, bronze & 45.1 & $\mathrm{Mg}$ \\
\hline Other waste & $1,635.84$ & $\mathrm{Mg}$ \\
\hline Cables & 21.31 & $\mathrm{Mg}$ \\
\hline Municipal Solid Waste-MSW & 49.82 & $\mathrm{Mg}$ \\
\hline
\end{tabular}

${ }^{\mathrm{a}}$ Carbon and graphite carburizer, material for carburization of steel 
Fig. 2 Converter gas cleaning system

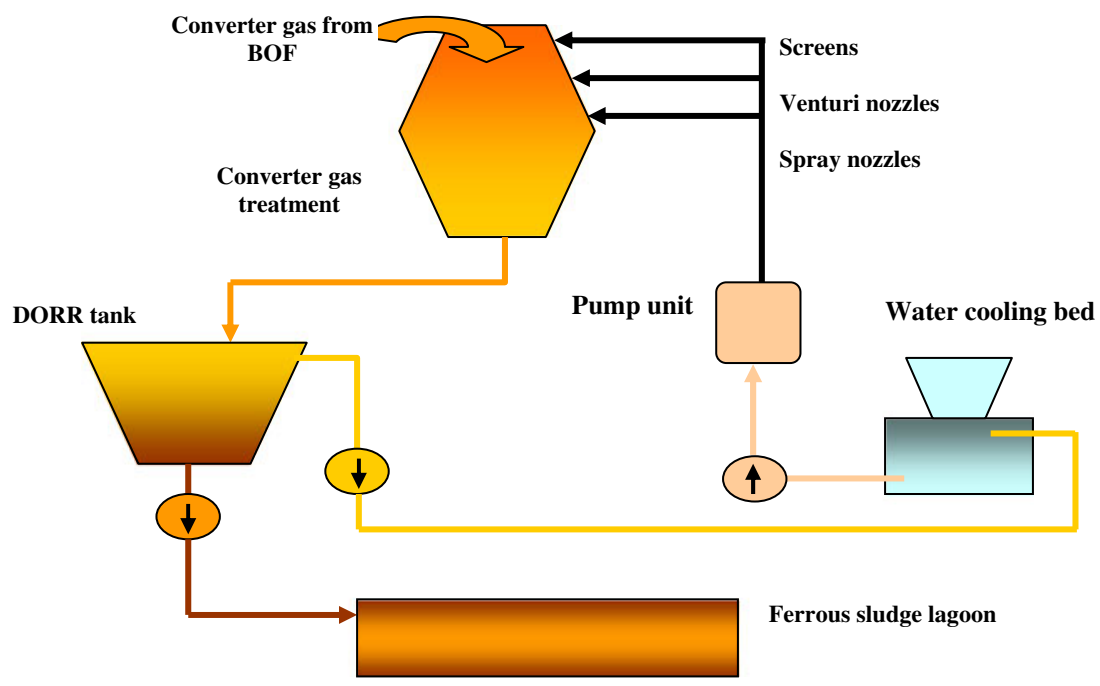

required a lot of data (Finnveden et al. 2009). The complete data inventory is documented and presented in Mittal (2007). In the present case study, the evaluated system does not include anything upstream from the steel production. The main properties of energy carriers used in AMBOF as well as air emissions associated with steelmaking in AMBOF have been shown in Table 3 .

\section{Air pollutants}

\section{$4.1 \mathrm{CO}_{2}$}

In 2005, $\mathrm{CO}_{2}$ emission was estimated on the following formula under the European Commission's 2004/156/EC Decision pursuant to Directive 2003/87/EC of the European Parliament and stated in the Council Decision on 18 July 2007 (Official Journal of the European Union 2007):

$\mathrm{Co}_{2}$ emission $=$ activity data $\times$ emission factor $\times$ oxidation(conversion) factor.

The energy and fuel values of the LCI input were calculated using data from Mazur et al. (2006). Fuels and energy indicators for the production of $1 \mathrm{Mg}$ of steel according to the European Union and the AMBOF models for 2005 are presented in Tables 4 and 5.

Under the European Community program establishing a scheme for greenhouse gas emission allowance trading, the Polish Government directive established a scheme for greenhouse gas emission credits for AMP for the year 2005. The guidelines laid down in that directive determined individual permitted emission limit values in accordance with the above-mentioned directive. For example, if $\mathrm{CO}_{2}$ emissions from unit 1 were lower than the permitted emission limit, the remaining emission credits (allowance) were used by other AMP units.

The limits were laid down by the Regulation of the Council of Ministers on the adoption of a National Allocation Plan for emissions of carbon dioxide for the years 2005-2007 issued on 27 December 2005 (Journal of Laws 2005b). The annual limit allocated to AMP was 3,165,400 number of permits (carbon credits). In accordance with this legislation, the annual report of the $\mathrm{CO}_{2}$ emissions was verified by the Małopolska Provincial Office Inspector of Environment. In each case, the permitted $\mathrm{CO}_{2}$ emissions depend on the nature of installations.

The carbon emission factor depends highly on the heat capacity of carbon in the fuel. Carbon oxidation factor is another indicator for $\mathrm{CO}_{2}$ emission characteristics of fuel. In fact, it is also related to combustion equipments, technology and operation conditions. The main properties of the energy carriers used in AMP are given in Bieda (2011).

$\mathrm{CO}_{2}$ emissions are in line with the emission credits for AMP. Monitoring and standard criteria for $\mathrm{CO}_{2}$ emissions were specified in the Decision of Małopolska Provincial

Table 4 Fuels and energy indicators for the production of $1 \mathrm{Mg}$ of steel in the AMBOF model: forecast

\begin{tabular}{llccc}
\hline \multirow{2}{*}{ Fuels } & \multirow{4}{*}{ Unit } & \multicolumn{2}{l}{ Year } \\
\cline { 3 - 5 } & & 2004 & 2006 & $2007-2016$ \\
\hline Blast furnace gas & $\mathrm{m}^{3} / \mathrm{Mg}$ steel & 0.45 & 0.45 & 0.45 \\
Coke oven gas & $\mathrm{m}^{3} / \mathrm{Mg}$ steel & 7.88 & 7.88 & 7.88 \\
Natural gas & $\mathrm{m}^{3} / \mathrm{Mg}$ steel & 6.36 & 6.36 & 6.36 \\
Electric energy & $\mathrm{kWh} / \mathrm{Mg}$ steel & 26.82 & 26.82 & 26.82 \\
Steam & $\mathrm{kg} / \mathrm{Mg}$ steel & 12.9 & $\mathrm{~N} / \mathrm{A}$ & $\mathrm{N} / \mathrm{A}$ \\
Air & $\mathrm{m}_{\mathrm{u}}{ }^{3} / \mathrm{Mg}$ steel & 54 & $\mathrm{~N} / \mathrm{A}$ & $\mathrm{N} / \mathrm{A}$ \\
Oxygen & $\mathrm{m}_{\mathrm{u}}{ }^{3} / \mathrm{Mg}$ steel & 64.12 & $\mathrm{~N} / \mathrm{A}$ & N/A \\
Heat & $\mathrm{GJ} / \mathrm{Mg}$ steel & 0.01 & N/A & N/A \\
\hline
\end{tabular}


Table 5 Fuels and energy indicators for the production of $1 \mathrm{Mg}$ of steel according to the European Union (EU) and the AMBOF models

\begin{tabular}{lllr}
\hline Fuels & Unit & EU & AMBOF \\
\hline Blast furnace gas & $\mathrm{MJ} / \mathrm{Mg}$ liquid steel & N.A. & 0.45 \\
Coke oven gas & $\mathrm{MJ} / \mathrm{Mg}$ liquid steel & N.A. & 7.88 \\
Natural gas & $\mathrm{MJ} / \mathrm{Mg}$ liquid steel & $20-55$ & 6.36 \\
Electric energy & $\mathrm{MJ} / \mathrm{Mg}$ liquid steel & $38-120$ & 96.55 \\
\hline
\end{tabular}

Office in Krakow dated 11 April 2006 (Decyzja 2006). This decision also set forth legal emission limits for the maximum $\mathrm{CO}_{2}$ emissions in 2005 (Journal of Laws 2005a).

\section{Water pollutants and particulate air pollution}

In $2005,341,908,741 \mathrm{Mg}$ of waste produced during the steelmaking process in a BOF plant were sorted and recycled. Generally, the infrastructure for waste recycling is well-established. Waste is transferred either to BOF steelmaking routes or to other AMP installations. If a recycling operation is not available in AMP, the waste is fed to external units for such treatment (recycling). Otherwise, the waste is landfilled.

\section{Discussion}

Converter gas is considered to be waste gas. The outlet composition for converter gas mainly consists of $\mathrm{N}_{2}+\mathrm{Ar}$, $\mathrm{CO}, \mathrm{CO}_{2}$ and $\mathrm{H}_{2}$ (see Table 6). Carbon monoxide has the most significant energy content value between the converter gas components. During the melt process, the produced converter gas values range from 50 to $80 \mathrm{~m}^{3} \mathrm{t}$ of steel. The temperature of converter gas on the converter outside is generally about $1,400 \div 1,700^{\circ} \mathrm{C}$, and the reason for this is the use of this medium for the saturated steam production with a pressure value of $2.3 \mathrm{MPa}$ at the maximal output (capacity) of $240 \mathrm{Mg} / \mathrm{h}$ in the top period of carbon burning.

Table 6 BOF gas composition

\begin{tabular}{lccc}
\hline Component & Unit & Average value & Min-Max values \\
\hline $\mathrm{CO}$ & $\mathrm{vol} \%$ & 72.5 & $55-80$ \\
$\mathrm{H}_{2}$ & $\mathrm{vol} \%$ & 3.3 & $2-10$ \\
$\mathrm{CO}_{2}$ & $\mathrm{vol.} \%$ & 16.2 & $10-18$ \\
$\mathrm{~N}_{2}+\mathrm{Ar}$ & $\mathrm{vol.} \%$ & 8.0 & $8-26$ \\
Density & $\mathrm{kg} / \mathrm{m}^{3}$ & 1.33 & $1.32-1.38$ \\
Upper calorific value & $\mathrm{kJ} / \mathrm{m}^{3}$ & 9,515 & $7,000-10,000$ \\
Lower calorific value & $\mathrm{kJ} / \mathrm{m}^{3}$ & 9,580 & $7,000-10,000$ \\
\hline
\end{tabular}

Generally, surplus of the converter gas nonburned in steam boilers is transferred to flare stacks and combusted. Air emissions are usually negligible due to flaring when compared to the energy process stage of air emissions. In various types of fuels for internal electricity production, Iosif et al. (2009) also examined the converter gas. In the study conducted by Hellberg et al. (2005), the possible utilization of converter gas and coke oven gas in an integrated metallurgical plant was investigated for replacement of oil with gas as a reducing agent in a modern blast furnace. Not surprisingly, the main results of this study show that the coke oven gas is combusted more completely, which leads to a higher flame temperature of the blast than converter gas.

Industrial water input reaches $12,246,295 \mathrm{~m}^{3}$ for the converter gas cleaning process. The Vistula and Dłubnia rivers serve as industrial water supply sources for the AMP (Fig. 3). Water softening and water demineralization for BOF are produced in ArcelorMittal Steel Power Plant Poland (Bieda 2011).

Calcium oxide is the material used for slag forming (Table 3-summarized in LCI data material input). Fuel and energy quantities have been calculated using indicators for the production of $1 \mathrm{Mg}$ of steel according to the AMBOF models, given in Table 4, because of the lack of fuels and energy datasets for the year 2005. It is possible to use indicators from previous and next years because no changes have been observed regarding fuel and energy indicators in 2004 in comparison to 2006-2007 as well as 2006-2016 (forecast), listed in Table 4. AMBOF indicators comply with the limits specified by the EU (see Table 5). Broadbent (2011) reported that recycling of steel in the BOF route is beneficial because it saves raw materials and other resources. Moreover, scrap recycled in the BOF displaces the energy and emissions associated with primary iron production. The benefits of recycling steel are also provided in the cradle-to-gate data, incorporating the product's end of life. The BOF steelmaking process is presented by Iosif et al. (2009) in the assessment study of the environmental impact of the classical steelmaking route. The objective of the above-mentioned work was to develop a new way of carrying out the LCI of the classical steelmaking route based on the interconnection between the LCA and the process simulation software Aspen Plus ${ }^{\mathrm{TM}}$ (Advanced System for Process Engineering). The functional unit was $1 \mathrm{t}$ of hot rolled coil produced in a classical integrated steelmaking plant. The comparison with the present study is not possible since the FU chosen for the present study is $1,677,987 \mathrm{Mg}$ of steel produced by the BOF steelmaking process. The International Iron and Steel Institute (IISI) has done a commendable job in the planning, design and implementation of the IISI Worldwide LCI Database for Steel Industry Products. The full methodological report including the critical review according to ISO 14040, performed by B.P. Weidema, A. 
Fig. 3 Water flow diagram in AMSPP in Kraków

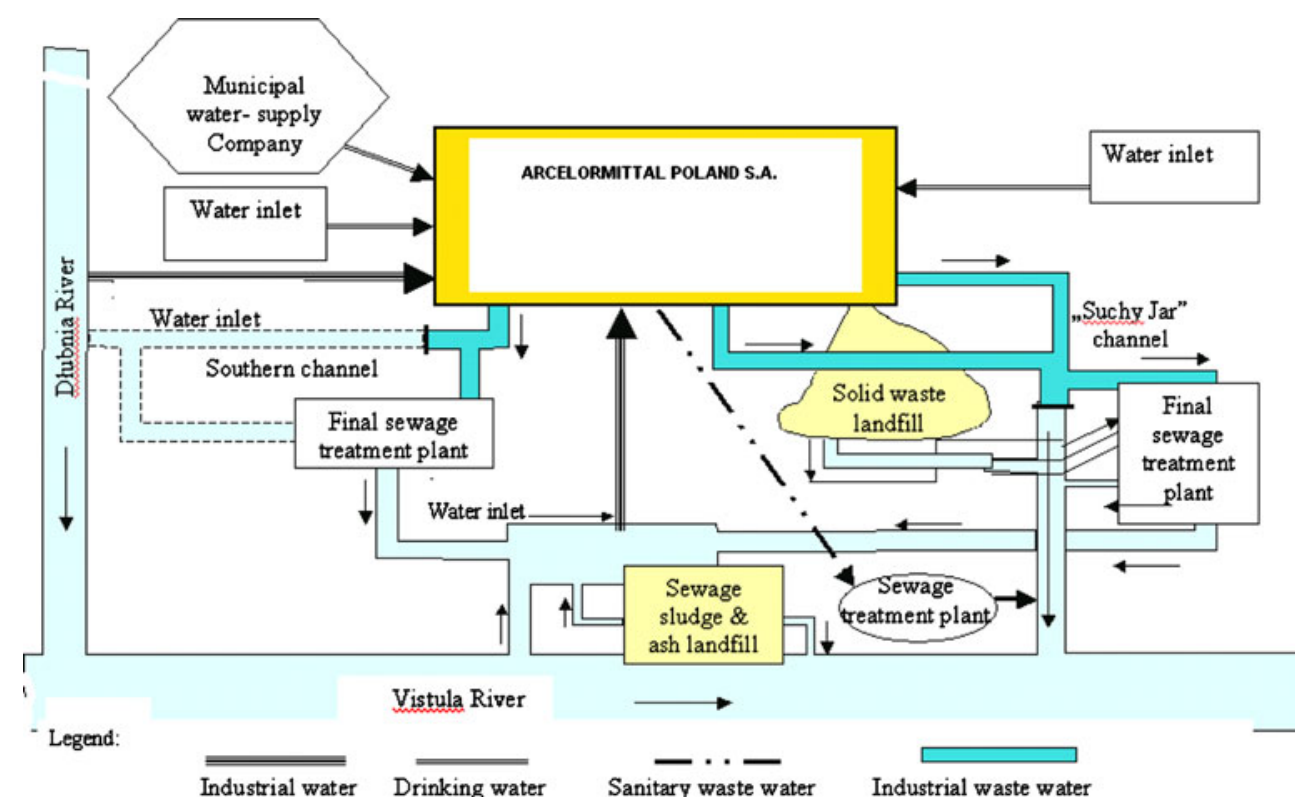

Inaba and G.A. Keoleian, is available on the website of the International Iron and Steel Institute (IISI 2002). The study was carried out for 1999-2000 data. In total, 50 sites operated by 28 companies including 34 blast furnace operations, 13 electric arc furnace operations and three direct reduction operations participated in the study. The companies contributing data to the LCI study account for $39.7 \%$ of global crude steel production outside of the former USSR and China. Mittal was not presented (Mittal was merged with Arcelor in 2006, and the new company was called ArcelorMittal). Companies in Europe and Far East Asia were wellrepresented, and a typical range of operating configurations included North America in the global averages. This level of coverage maintains the IISI LCI study as one of the most representative LCI studies ever carried out for a material, and it provides a sound basis for LCA studies relating to steel. Price (2003) highlighted the studies carried out by Eurofer (Orlandi et al. 2002) and IISI (2002) aimed at determining LCI on Stainless Steel Flat Products and Worldwide LCI Study for Steel Products, respectively. The experience and datasets gained from these studies have been extended in order to complete a LCI for global stainless steel (Price 2003). In Japan, the life cycle experts of the Japanese Iron and Steel Federation have completed an LCI study for flat and long stainless products and have agreed to allow this data to be aggregated into the global LCI for the International Stainless Steel Forum (ISSF). Similarly, in South Korea and North America, stainless steel LCI have been collected for flat and long products to make this a truly global concern. Moreover, Price (2003) recommends that the value on the LCI study must be realized internally and externally. The internal value creation is obtained from a comprehensive assessment of emissions, energy and material use throughout the process. The stainless steel companies from the Eurofer LCI have already received and used such an assessment tool. Externally, the value of an LCI can be developed in the case of ISSF for case studies to illustrate the applications of stainless steel as the material of choice. This database will be a valuable resource for LCA studies involving steel products. LCI is considered to be the step in which all the environmental loads (raw material consumption, air emissions, waste, etc.) generated by the steelmaking processes are identified and evaluated.

\section{Conclusions}

The LCI of steel production in AMBOF is focused on the production and operation results in 2005 as defined in the goal and scope. The output of the AMBOF steel LCI study is a set of gate-to-gate LCI data for steel production in BOF technology. This is the first tentative study to express steel production in Poland in terms of LCA/LCI in the steelmaking industry. The production of $1,677,987 \mathrm{Mg}$ of steel in 2005 was the selected FU. The quality of data input in this LCI study is very good. The rules were used in accordance with ISO standards. The methodological approach and boundaries that were made are transparent and fully documented. The purpose of this study is to help AMP authorities to solve environmental and technical aspects as well as to train steel industry people in the field of life cycle assessment. In addition, this study can be extended to other processes involved in steelmaking route (via sintering plant/hot rolling plant). Moreover, these results move the LCI study on the steelmaking process one step forward.

In conclusion, the LCI step was carried out in order to provide data for further LCA process. These data will be available for the LCIA step. The LCIA provides an analysis 
of collected data to evaluate contributions to various environmental impact categories. Thus, the LCIA will be introduced as the next step of LCA methodology. These data are available for interpretation - the final step of the LCA method where the collected data is analyzed in the context of methodology, scope and study goals and where the quality of study outcomes is assessed. Finally, a complementary paper will be produced and submitted to this journal in which LCIA will be discussed.

\section{Recommendations and outlook}

The research described in this paper can also serve as the basis for future work. The potential direction for future research is to develop the LCI datasets for the classical route of steel production. The study should cover the foreground processes: coking plant, sintering plant, blast furnace, BOF and hot rolling plant. A complementary paper will be produced and will be submitted to this journal in which LCIA will be discussed.

Acknowledgments The present scientific research was supported by science financial grant for the years 2011-2013. The author would like to thank: Mr. Jacek Wolinski and Mr. Wojciech Motyka from the ArcelorMittal Steel Poland SA, Kraków for discussion, materials and support received in relation to the presented subject, and Mrs. J. Kulczycka and Mrs. A. Henclik from the Polish Academy of Science for invaluable discussions.

Open Access This article is distributed under the terms of the Creative Commons Attribution Noncommercial License which permits any noncommercial use, distribution, and reproduction in any medium, provided the original author(s) and source are credited.

\section{References}

Bieda B (2011) Life cycle inventory of energy production in ArcelorMittal steel power plant Poland S.A. in Krakow, Poland. Int J Life Cycle Assess 16:503-511

Broadbent C (2011) Frequently asked questions: life cycle inventory database for steel industry products. Worldsteel Association. http://www.worldsteel.org/pictures/programfiles/worldsteel_ LCA_FAQ_Feb2011.pdf. Accessed 10 August 2011
Decyzja Urzędu Wojewódzkiego-ŚR.III.JD.6610-16-1-05/06 (2006) (in Polish)

Finnveden G, Hauschild MZ, Ekvall T, Guinée J, Heijungs R, Hellweg S, Koehler A, Pennington D, Suh S (2009) Recent developments in life cycle assessment. J Environ Manag 91(1):1-21

Hellberg P, Lage T, Jonsson LI, Jönsson PG (2005) A mathematical model of a blast furnace injection Tuyere. Steel Res Int 76 (11):755-763

IISI-International Iron and Steel Institute (2002) IISI Life Cycle Inventory Study for steel industry products. Worldwide LCI Database for Steel Industry Products. http://www.worldsteel.org. Accessed 12 May 2009

Iosif A-M, Birat J-P, Mirgaux O, Ablitzer D (2009) Reduction of $\mathrm{CO}_{2}$ emissions in the steel industry based on LCA methodology. http:// www.ulcos.org/en/docs/Ref33\%20-\%20TMS_CO 2 _correct_1. pdf. Accessed 10 Aug 2011

Journal of Laws (2005a) No. 260, Item 2181 of 29.12.2005 http:// lex.pl/serwis/du/2005/spis260.htm. Accessed 20 Jan 2010 (in Polish)

Journal of Laws (2005b) No. 264, Item 2206 of 27.12.2005. http://msp. money.pl/akty_prawne/dzienniki_ustaw/rozporzadzenie;rady; ministrow; z dnia, dziennik ustaw,2005,264,2206.html. Accessed 20 Jan 2010 (in Polish)

Kulczycka J, Henclik (2009) Ocena wpływu cyklu życia procesów wytwórczych na Wydziałach Surowcowych i Wytwarzania Stali Huty ArcelorMittal Poland SA, Oddział w Krakowie. Polish Ahademy of Sciences, Krakow (Polish)

Mazur M, Gruszczyński S, Bergier T, Bogacki M, Grzesik K, Oleniacz R, Szczygłowski P, Wszołek T, Wszołek W, Ciesielka W, Litwa P, Kłaczyński M (2006) Wniosek o wydanie pozwolenia zintegrowanego dla Instalacji energetycznego spalania paliw (Siłowni) Mittal Steel Poland S.A. Oddział w Krakowie-Streszczenie (w języku niespecjalistycznym), Kraków, 2006 (in Polish)

Mittal Poland (2003) Energetic department document, Kraków, (in Polish)

Mittal Poland (2007) Environmental impact report (in Polish)

Official Journal of the European Union (2007) Commission Decision of 18 July 2007 (notified under document number C 3416). http:// eur-lex.europa.eu/LexUriServ/LexUriServ.do?uri=OJ: L:2007:229:0001:0085:EN:PDF. Accessed 25 March 2010

Orlandi M-C, Hay A, Koundakjian P (2002) Europeana LCI on stainless steel flat products

PN-EN ISO (2009) Environmental management-life cycle assessment-principles and framework (2009)

Price E (2003) Global stainless steel life cycle inventories. BSSA Conference, Sheffield, UK http://www.bssa.org.uk/cms/File/ Conf $\% 2003 \% 20$ Global\%2055\%20Life\%20Cyde\%20Inventory. pdf. Accessed 10 Aug 2011

Szuba I (2004) Organizacja składowania odpadów hutniczych na przykładzie składowisk Huty im. Tadeusza Sendzimira w Krakowie, engineering thesis. Radom 2004 (in Polish) 